\title{
Microbial Quality Evaluation of Zobo Drink Sold in University of Maiduguri
}

\author{
Bristone $\mathrm{C}^{1 *}$, Mariyam $\mathrm{K}^{1}$, Ogori $\mathrm{AF}^{2}$, Badau $\mathrm{MH}^{1}$ and Joeguluba $\mathbf{0}^{3}$ \\ ${ }^{1}$ Department of Food Science and Technology University of Maiduguri, Maiduguri, \\ Nigeria \\ ${ }^{2}$ Department of Home sciences, Federal University Gashua, Gashua, Nigeria \\ ${ }^{3}$ Department of Agricultural Education Federal College of Education, Kontagora, \\ Nigeria
}

*Corresponding author: Bristone C, Department of Food Science and Technology University of Maiduguri, Maiduguri, Nigeria, Tel: +2347036423913; E-mail: bristonecharles@yahoo.com

\section{Research Article \\ Volume 3 Issue 1}

Received Date: December 15, 2017

Published Date: February 03, 2018

\section{Abstract}

Determination of the microbial quality of Zobo drink was carried out to ascertain its health risk due to increase of consumers' interest. The total aerobic bacteria plate count, coliform count, moulds count, yeasts count, and staphylococcus count of Zobo drink sold within the University of Maiduguri Campus were investigated. The method used was collection and analysis of samples from four cardinal locations (North East, North West, South East and South West) of the University of Maiduguri. A total of 12 samples, three from each cardinal point were analyzed for the above named organisms by culturing on selective media (corn meal, mannitol salt, nutrient, macConkey and potatoes dextrose agar). Results obtained shows that the total bacteria plate count ranged from $6.9 \times 10^{3}$ to $9.6 \times 10^{3} \mathrm{CFU} / \mathrm{ml}$, total coliform count ranged from $3.7 \times 10^{3}$ to $6.0 \times 10^{3} \mathrm{CFU} / \mathrm{ml}$, total moulds count ranged from $1.3 \times 10^{3}$ to $2.3 \times 10^{3} \mathrm{CFU} / \mathrm{ml}$, total yeasts count ranged from $1.6 \times 10^{3}$ to $2.4 \times 10^{3} \mathrm{CFU} / \mathrm{ml}$ and total staphylococcus count ranged from $1.0 \times 10^{3}$ to $1.4 \times 10^{3} \mathrm{CFU} / \mathrm{ml}$. The type of microorganisms identified based on their morphological and biochemical characteristics are E. coli, Candida albicans, Staphylococcus, Klebsiella, Shigella and Salmonella sp. Their percentage occurrences from the different samples were also observed. This study reviled facts about possible exposure of consumers of commercial Zobo to health hazard. So, a good hygienic practice during its processing is recommended to eliminate contaminants. The use of modern technology for its processing would also reduce this health risk.

Keywords: Zobo; Drink; Microbial counts; Evaluation; Quality 


\section{Food Science and Nutrition Technology}

\section{Introduction}

Zobo is a red non-alcoholic local beverage made from different varieties of dried petal, succulent aqueous acid extracts of Roselle calyx [1]. The beverage has a sour taste and often sweetened. Zobo is a name derived from "Zoborodo ". It is a local Hausa name as reported by Ayandele [2]. Hibiscus sabdariffa has other names such as -'Gongura" in Hindi, "Krajeab" in Thailand, "Bissap" in Senegal, "Sorrel" in Carribean [3]. This non-alcoholic drink is quite popular especially in Northern Nigeria [4].

The increase in religious and health campaign against alcoholic beverages in Nigeria and the subsequent decrease in the consumption of alcoholic beverages in certain areas have made Zobo to be a great potential local alternative to imported drinks such as red wine. Zobo is found to be rich in vitamin, carbohydrate, protein, calcium, and iron, mineral and other antioxidants. Besides these, it has been used in folk medicine as diuretic, mild laxative treatment for cardiac and nerve diseases and also management of cancer. Zobo is also reported to be a good traditional medicine for the treatment of several diseases like hypertension and urinary tract infection [5].

Zobo calyx of Roselle plant has different varieties. The dried matured calyx of the flower of Hibiscus plant may be red, bright red or brown which can yield different colours of Zobo drinks [5].

Zobo calvx of Hibiscus sabdariffa plant is an annual herb that is widely cultivated in India and Africa [6]. There is an increase in demand of Zobo calyx for the production of Zobo drink due to its low price and health benefits. The economic recession in Nigeria has made Zobo an acceptable choice too many. This has led to its consumption by millions of people from different socioeconomic class [7]. The chilled drinks of Zobo from shops are being used as a source of refreshment in different gathering. This drink is usually consumed by many groups of people because of its non-alcoholic content and refreshing taste [3].

Ayandele [2] reported that spices usually added being an agricultural commodity may contain high level of microbial load. A large number of lactic acid bacteria, coliform, mould and yeast in Zobo drinks have been reported. These microorganisms have implication for food spoilage and possible infection as they utilize the carbohydrate content of Zobo drink for fermentation process to produce undesirable compounds. Also according to the research carried out by Amusa, et al. [6] indicated that the consumption of this local drink is of public health significance. The local drink may also serve as vehicle for zoonotic and food-borne diseases or possible transmission of pathogens such as Staphylococcosis, Salmonellosis, Brucelosis, Tuberculosis, Escherichia coli as reported by Amusa, et al. [6] and Ayandele [2].

It is expected that consumption of Zobo drink is of more health benefits. However, the recent increase in food infections and poisoning around the world affected the derivatives of these benefits [7]. In spite of nutritional challenges of Zobo drinks, it is also often contaminated with diverse group of microorganisms which could be harmful to the individual who consumed it. Packaging materials may also serve as a source of contamination if not well sterilized. School premises are not exception of this problem. Similarly, it is of public health concern in universities where tools for health examination are available but sometimes being neglected. So, institution such as University of Maiduguri where standard hygiene is supposed to be checked and maintained has made this research significant.

The consumption of local drink is of public health concern and so there is a need to evaluate particularly the microbiological quality of Zobo sold within the University of Maiduguri to ascertain its level of contamination.

\section{Materials and Method}

\section{Study area}

This research was conducted within University of Maiduguri. The food samples (Zobo beverage) are sold within the University of Maiduguri campus, Borno state. All chemicals and reagents that were used for this study were obtained from the Department of Food Science and Technology, University of Maiduguri. The samples were collected from the four cardinal point of the University of Maiduguri. Each of the three samples collected from the four cardinal points were analysed and the average taken as described by Sylvester, et al. [8].

\section{Description of Food}

Zobo is a non- alcoholic beverage, it is a reddish liquid drink that have a sour test. It is obtained from the calyces of Hibiscus sabalariffa and has a shelf life of about 2-3 days under room temperature storage condition as reported by Bello, et al. [9]. 


\section{Food Science and Nutrition Technology}

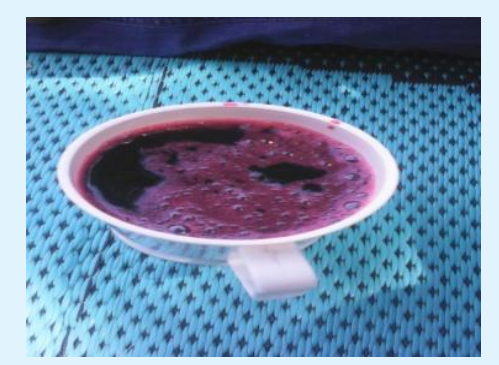

Figure 1: Zobo drink

\section{Sample and sampling}

Three samples each was purchased from the four cardinal point of the University of Maiduguri, representing different sources and manufacturing processes. It was aseptically transferred into a sterile container. The samples were placed in an iced cooler and immediately transferred to laboratory for microbiological analysis as describe by Ayandele [2].

\section{Sterilization of material}

All materials that were used in the course of this project such as glassware's were properly washed with detergent and water to remove dirty and contaminations and dried properly. The wash glassware's was sterilized in a portable laboratory autoclave at a temperature of $121^{\circ} \mathrm{C}$ for 15 minutes as described by Bukar, et al [10]. All media used was also sterilized in the autoclave at a temperature of $121^{\circ} \mathrm{C}$ for 15 minutes Nwachukwu and Osuocha [11].

\section{Preparations of culture media}

Nutrient agar (NA): Nutrient Agar was prepared by dissolving $28 \mathrm{~g}$ of nutrient agar powder in $1000 \mathrm{ml}$ of distilled water in a clean flask. The mouth of the flask was plugged with non-absorbent cotton wool wrapped with aluminum foil paper that was extended up to the neck of the flask as described by Sylvester, et al. [8]. The flask was placed on a bunsen flame and allows to boil and mix completely. It was sterilized in an autoclave at $12 \mathrm{I}^{\circ} \mathrm{C}$ for 15 minutes and allowed to cool to $45^{\circ} \mathrm{C}$ and aseptically dispensed into Petri dishes. Nutrient agar was used for the total bacterial aerobic plate count [12].

Macron key Agar (MA): This agar was prepared by dissolving bile salt, Then $48.5 \mathrm{~g}$ of the powder was dissolved in $1000 \mathrm{ml}$ of distilled water. The $\mathrm{pH}$ was adjusted to 7.8 . It was autoclave at $121^{\circ} \mathrm{C}$ for 15 minutes and allowed to cool to a temperature of $45-50^{\circ} \mathrm{C}$ before pouring into plates. This was used to determine coliforms as described by Cheesbrough [13]. This is a selective and differential media designed to isolate and differentiate organism based on their ability to ferment lactose as described by Sebastia, et al. [14].

Corn meal agar (CMA): Corn meal agar was used to isolate yeast and it's prepared by dissolving 17 grams of corn meal powder in a $1000 \mathrm{ml}$ of distilled water. The mixture was heated gently to dissolve the medium completely. $1 \%$ of polysorbate was added and sterilized in autoclave at $121^{\circ} \mathrm{C}$ for 15 minutes. It was cool at room temperature before pouring into petri dish containing 1 $\mathrm{ml}$ of the sample as described by Zumbes et al. [1]

Potatoes dextrose agar (PDA): The medium PDA was prepared by using 39 grams of potatoes dextrose agar powder. It was dissolved in $1000 \mathrm{ml}$ distilled water. It was heated to boiling, in order to get mixed completely. Then sterilized in an autoclave at $121^{\circ} \mathrm{C}$ for 15 minutes, this particular media will be used to this particular media [15].

Mannitol salt agar (MSA): The medium was prepared by dissolving 108 grams of mannitol salt agar in $1000 \mathrm{ml}$ of distilled water, after which it was allowed to stand for 10 minutes, swirled to dissolve properly. The mixture was sterilized in an autoclave at $121^{\circ} \mathrm{C}$ for 15 minutes and allowed to cool to a temperature of $45^{\circ} \mathrm{C}$ before pouring into the appropriate petri dish as described by Fowoyo [16]. Mannitol salt agar was used to determine and enumerate the bacteria Staphylococcus.

\section{Microbiological Analysis}

Serial dilution: Distilled water was used for serial dilution, $9 \mathrm{ml}$ each was pipette into a sterile screw cap test tube, the distilled water in the test tube was autoclaved at $121^{\circ} \mathrm{C}$ for 15 minutes and allowed to cool temperature of $45^{\circ} \mathrm{C}$ before serial dilution. In each case of dilution, $1 \mathrm{ml}$ of Zobo drink was pipette into $9 \mathrm{ml}$ tube. The process continues until dilution up to $10^{3}$ of the dilution factor was made inoculated into three well labelled petric dish as described by Chidi, et al [17].

Plating of culture and incubation: Pour plate method was used for plating the samples, $1 \mathrm{ml}$ of the diluents of $10^{3}$ was transferred to the petric dish, this was done in triplicate and well labeled $\left(10^{3}, 10^{3}, 10^{3}\right)$. This procedure was done for each of the samples taken from the four cardinal point. The agar was poured into the pertic dish containing $1 \mathrm{ml}$ of the sample, slightly shaken and allowed to solidify and transferred into the incubator at $37^{\circ} \mathrm{C}$ for 


\section{Food Science and Nutrition Technology}

24 hours exception of yeast and mould which extended to 48 hours for easy identification according to the study carried out by Sanni and Adesulu [18].

Viable cell count: The representative petric dish incubated was visualized under a colony counting machine and was used to count the total bacterial count (labtech, india) and result was expressed as colony forming unit per millilitre (CFU/ml) at the end of the count as reported by Olayemi, et al. [19].

Identification of microbial isolate: Identification of the microbial isolate was performed using classical methods based on their morphological and biochemical characteristic with reference to systematic manual of bacteriology described by Cheesbrough [13].

Gram staining technique: Gram staining reaction has the wide application that is capable of distinguishing virtually all bacteria into one of two large group - gram positive or gram negative as describe Dr Hans Christian Gram (1884). Smear of each isolate was made on the slide and heat fixed. Primary stain (crystal violet) was added in drops. Lugols iodine was added for 45 seconds decolorized with acetone and washed with water. It was then air dried examined at Xl00 under oil immersion as described by Bello, et al. [9]. Positive gram staining appears purple and negative grams staining appeared pink.

Motility: The medium used for motility test (agar with concentration of $0.5 \%$ ) was inoculated with test organism. A stab of each inoculate was made at the centre of each tube. The tube at $37^{\circ} \mathrm{C}$ was incubated for 24 hours. A diffused growth at the place of inoculation was considered as positive and restricted growth was considered as negative [20].

Catalase test: Catalase test was carried out using a drop of hydrogen peroxide. $2 \mathrm{ml}$ of $3 \%$ hydrogen peroxide $\left(\mathrm{H}_{2} \mathrm{O}_{2}\right)$ was placed in a clean test tube. A sterile wire loop was used to pick a colony of the test organism and mixed with $2 \mathrm{ml}$ of $3 \%$ hydrogen peroxide $\left(\mathrm{H}_{2} \mathrm{O}_{2}\right)$ in the test tube and observed for the production of gas bubbles which indicates a positive reaction. This test was used to identify Staphylococcus Aureus [21].

Coagulase test: The use of blood plasma is being introduced in coagulase test. A loop full of human plasma was added to culture isolate on a slide. Positive isolate gave agglutination reagent with plasma. Test was also carried out at $37^{\circ} \mathrm{C}$ for 24 hours' positive tubes showed coagulation of the plasma in the tube. This test was used to identify Staphylococcus Aureus [21].

Citrate utilization: The ability of an organism to utilize citrate as the only carbon and energy source for growth and ammonium salt as the sole source of nitrogen. Slants of citrate agar were made and the isolates were streaked on the surface of the slant. Positive result gave blue coloration and negative result retained the original colour. The test was used to identify the coli forms as described by Sylvester, et al. [8].

Urease Test: Bacteria, particularly those growing naturally in an environment exposed to urine, may decompose urea by means of the enzymes urease. This ability was tested for using Christensen medium with heavy inoculation of the isolates was made and the agar slants in tube was observed after 24 hours and then incubated further for hours. 'This test was used to identify coli forms as reported by Musa and Hamm (2013) [22].

Oxidase test: A few drops of kova's reagent were added to piece of filter paper on a petri dish. The bacteria isolates were then smeared on the filter paper with a glass rod. The paper was observed. Positive result gave a dark purple color while negative result showed no color change. This test was used to identify coliforms. As reported by James, et al. [21].

Indole test: This was done by colorimetric reaction with P-Dimethyl-amino-benzaldehyde (Kovac reagent) to determine the ability of isolate to decomposed the amino acid, tryptophane into indole, Peptone Broth was prepared and dispensed in test tube and were inoculated with the isolate and incubated at $37 \mathrm{oC}$ for 4 days. $0.5 \mathrm{ml}$ of Kovac reagent was added to each and was tube shaking gently. Positive results were characterized with red alcohol layer; the negative result gives a yellow colour at the junction of the medium. The test used for identification of Escherichia coli as described by Ayandele [2].

Methyl red: This was used to detect the production of sufficient acid during fermentation of glucouse which indicated by change in colour of the methyl red indicator. Isolates were inoculated into tube of previously prepared glucose peptone and incubated at $37^{\circ} \mathrm{C}$ for 2 days. Then 5 drops of methyl red solution were added to each tube and colour change was observed. Positive result gave yellow with the indicator as reported by Raima [23].

Voges - proskauer: Tubes of glucose phosphate peptone water were inoculated and incubated at $37^{\circ} \mathrm{C}$ for 2 days. 1 


\section{Food Science and Nutrition Technology}

$\mathrm{ml}$ of $40 \% \mathrm{KOH}$ and $3 \mathrm{ml}$ of $5 \%$ solution of 2-naphrol in absolute ethanol was added to each tube. A positive result gives crimson colour in 30 minutes [12].

Isolation and Identification of yeast (Candida albicans): The presence of Candida albicans was distinguished from the other yeast by the germ tube test using corn meal agar as described by Sanni and Adesulu (18). A straight wire was used to pick of a colony from the surface of potatoes dextrose agar, a deep cut was made on the corn meal agar. A sterile flamed cover slip was plates over the side at inoculum and the plate incubated at $37^{\circ} \mathrm{C}$ for 24 hours. The cover slip was examined for streaks under microscope using the low power objective, the presence of mycelium bearing ball-like cluster of budding cell and thick walled chlamydospores is characteristic of Candida aibicans albicans Briade, et al. [24].
Statical Analysis: All data were analysed using Microsoft excel program as reported by Zumes, et al. [1]

\section{Results and Discussion}

(Table 1) showed the mean total of microbial count of Zobo drink on different culture media from the four cardinal points within the University of Maiduguri. The total bacteria plate count ranged from $6.9 \times 10^{3}$ to $9.6 \mathrm{x}$ $10^{3} \mathrm{CFU} / \mathrm{ml}$, total coliform count ranged from $3.7 \times 10^{3}$ to $6.0 \times 10^{3} \mathrm{CFU} / \mathrm{ml}$, total moulds count ranged from $1.3 \mathrm{x}$ $10^{3}$ to $2.3 \times 10^{3} \mathrm{CFU} / \mathrm{ml}$, total yeasts count ranged from $1.6 \times 10^{3}$ to $2.4 \times 10^{3} \mathrm{CFU} / \mathrm{ml}$ and total staphylococcus count ranged from $1.0 \times 10^{3}$ to $1.4 \times 10^{3} \mathrm{CFU} / \mathrm{ml}$. Each of these result represents an average value which corresponds with the result obtained reported by Egbere, et al. [4].

\begin{tabular}{|c|c|c|c|c|c|}
\hline Sample & TBC & TCC & TSTC & TMC & TYC \\
\hline \multicolumn{5}{|c|}{ South East (Commercial Area) } \\
\hline A & $7.1 \times 10^{3}$ & $5.1 \times 10^{3}$ & $1.2 \times 10^{3}$ & $1.6 \times 10^{3}$ & $1.7 \times 10^{3}$ \\
\hline B & $7.0 \times 10^{3}$ & $4.3 \times 10^{3}$ & $1.0 \times 10^{3}$ & $1.7 \times 10^{3}$ & $1.8 \times 10^{3}$ \\
\hline C & $8.6 \times 10^{3}$ & $5.3 \times 10^{3}$ & $1.3 \times 10^{3}$ & $1.6 \times 10^{3}$ & $1.3 \times 10^{3}$ \\
\hline \multicolumn{5}{|c|}{ South West (Acada Area) } \\
\hline D & $7.1 \times 10^{3}$ & $4.0 \times 10^{3}$ & $1.0 \times 10^{3}$ & $2.1 \times 10^{3}$ & $1.6 \times 10^{3}$ \\
\hline E & $7.1 \times 10^{3}$ & $5.0 \times 10^{3}$ & $1.2 \times 10^{3}$ & $1.8 \times 10^{3}$ & $2.3 \times 10^{3}$ \\
\hline F & $8.1 \times 10^{3}$ & $4.7 \times 10^{3}$ & $1.1 \times 10^{3}$ & $2.4 \times 10^{3}$ & $2.0 \times 10^{3}$ \\
\hline \multicolumn{7}{|c|}{ North East (Complex Area) } \\
\hline G & $8.2 \times 10^{3}$ & $3.7 \times 10^{3}$ & $1.4 \times 10^{3}$ & $2.0 \times 10^{3}$ & $2.0 \times 10^{3}$ \\
\hline H & $6.9 \times 10^{3}$ & $4.6 \times 10^{3}$ & $1.2 \times 10^{3}$ & $1.6 \times 10^{3}$ & $1.8 \times 10^{3}$ \\
\hline I & $9.6 \times 10^{3}$ & $6.0 \times 10^{3}$ & $1.2 \times 10^{3}$ & $2.0 \times 10^{3}$ & $2.3 \times 10^{3}$ \\
\hline \multicolumn{7}{|c|}{ North West (Unimaid Quarters) } \\
\hline J & $9.4 \times 10^{3}$ & $4.7 \times 10^{3}$ & $1.3 \times 10^{3}$ & $2.0 \times 10^{3}$ & $2.2 \times 10^{3}$ \\
\hline K & $9.1 \times 10^{3}$ & $4.0 \times 10^{3}$ & $1.2 \times 10^{3}$ & $1.8 \times 10^{3}$ & $1.7 \times 10^{3}$ \\
\hline
\end{tabular}

Table1: Microbial count (CFU/ml) of Zobo drinks obtained from the University of Maiduguri

Each value is a mean of triplicate determination

Note: $T B C=$ Total bacterial count, $T T C=$ Total colifoms count, $T S T C=$ Total staphylococcus count,$T M C=$ total mould count, TYC $=$ Total yeast count

The samples with highest microbial count based on category are: sample I from the North West with total aerobic bacteria count of $9.6 \times 10^{3} \mathrm{CFU} / \mathrm{ml}$, followed by sample I from North East with total coliform count of $6.0 \mathrm{x}$ $10^{3} \mathrm{CFU} / \mathrm{ml}$, next to this one was sample F (South West) with $2.4 \times 10^{3} \mathrm{CFU} / \mathrm{ml}$ of total moulds count, followed by sample E (South West) and I (North East) both with $2.3 \mathrm{x}$ $10^{3} \mathrm{CFU} / \mathrm{ml}$ total yeasts count, and lastly sample G from North East with $1.4 \times 10^{3} \mathrm{CFU} / \mathrm{ml}$ of total staphylococcus count (Table 1). All samples indicated significant level of contamination. Their presence may be due to both pre and post contamination. Although all the samples were contaminated with varying levels of microbial counts that can be classified as unsatisfactory [1]. It is possible that the occurrence of these pathogens occurred during processing, which was reported as the major source of contamination of locally made drinks by Fowoyo [16]. Necessary precautions might have been neglected and as such contamination could be inevitable as reported by Musa and Hamza [22]. 


\section{Food Science and Nutrition Technology}

(Table 2 and 3) shows the isolation of Staphylococcus aureus (an enterotoxins producer). This organism was reported to be responsible for staphylococcal food poisoning, which may also cause similar effect in Zobo drink. From this study, samples of Zobo have revealed that Zobo drink can be a potential source of bio toxins which may cause health issues such as either being acute or chronic [19]. The presence of Staphylococcus aureus in Zobo drink is a pointer to largely poor hygiene, improper storage facilities and use of low quality raw material [2543]. The isolation of yeast from these drinks may be linked to contamination (Table 2 and 3). The percentage occurrence of E. coli was observed to be present in all the samples of Zobo drink. E. coli is an important member of the coli form group, which its presence could render beverage unsuitable for consumption. Staphylococcus aureus was also isolated from the samples. It is a normal floral of the skin, nose, and throat Musa and Hamza [22]. The presence of the following organisms which were identified could cause diseases like fever (salmonella), shigellosis (shigella), E. coli causes food poisoning and Staphylococcus aureus staphylococcal food infection and intoxication.

\begin{tabular}{|c|c|c|c|c|c|c|c|c|c|c|c|}
\hline $\begin{array}{c}\text { Cultural } \\
\text { characteristic }\end{array}$ & $\begin{array}{c}\text { Gram } \\
\text { reaction }\end{array}$ & $\begin{array}{c}\text { Motility } \\
\text { Test }\end{array}$ & Coagulase & Catalase & $\begin{array}{c}\text { Methyl } \\
\text { red test }\end{array}$ & test & $\begin{array}{c}\text { Citrate } \\
\text { text }\end{array}$ & $\begin{array}{c}\text { Oxidase } \\
\text { test }\end{array}$ & $\begin{array}{c}\text { Voges- } \\
\text { Proskauer }\end{array}$ & $\begin{array}{c}\text { Urease } \\
\text { test }\end{array}$ & Isolate \\
\hline $\begin{array}{c}\text { Smooth oily } \\
\text { lactose } \\
\text { farmenter }\end{array}$ & - -Rod & + & - & + & + & + & - & - & - & - & E.Coli \\
\hline $\begin{array}{c}\text { Smooth cream } \\
\text { colony }\end{array}$ & + cocci & - & + & + & + & + & - & - & - & - & Staphylococcus \\
\hline $\begin{array}{c}\text { Grey white } \\
\text { irregular colony }\end{array}$ & - -Rod & + & - & + & - & - & - & - & + & + & Klebsiella \\
\hline $\begin{array}{c}\text { Pale colour non } \\
\text { lactose } \\
\text { fermenting } \\
\text { colonies }\end{array}$ & - -Rod & - & + & + & + & - & + & - & - & - & Shigella spp \\
\hline $\begin{array}{c}\text { Smooth cream } \\
\text { colony }\end{array}$ & + cocci & - & + & + & + & + & - & - & - & - & $\begin{array}{c}\text { Staphylococcus } \\
\text { spp }\end{array}$ \\
\hline $\begin{array}{c}\text { Large grey whit } \\
\text { mucoid colonies }\end{array}$ & - -Rod & + & - & + & + & - & + & + & + & - & Salmonella spp \\
\hline
\end{tabular}

Table 2: Cultural, morphological and biochemical characteristics of bacterial isolate from Zobo drink Note: + = positive , - = negative

\begin{tabular}{|c|c|c|c|c|c|}
\hline Isolate & \multicolumn{5}{|c|}{ Sample location } \\
\hline & South East & South West & North East & North West & \% Occurance \\
\hline E.coli & + & + & + & + & 50 \\
\hline Salmonella & + & - & + & - & 25.5 \\
\hline S. aureus & + & + & + & + & 50 \\
\hline Shigella & - & - & + & - & 12.5 \\
\hline Candida albicans & - & - & + & + & 25 \\
\hline Shigella & + & + & - & + & 37.5 \\
\hline
\end{tabular}

Table 3: Percentage occurrence of microbial isolates in Zobo drinks

Note: - = Negative, + = Positive

Occurrences of these microorganisms are largely due to their presence in nature. Their association with foods such as the commercial Zobo may be as a result of poor hygiene or poor sanitary condition as reported by Raima [23]. The isolation of coliform bacteria in all the Zobo samples exceeds the recommended limit of zero coliform $/ \mathrm{ml}$ in drinks. These coliforms are potential hazard for human especially during food consumption [23]. Coliforms, whose natural habitat is the intestinal tract of man and animal, reviled possible association of these faecal indicators into the commercially procured Zobo. Their presence may also indicate the presence of 


\section{Food Science and Nutrition Technology}

faecal or contamination by sewage introduced into the Zobo via the use of contaminated water or from the unsanitary environment during processing [2].

\section{Conclusion}

It was reviled in this study the type of microorganisms encountered. These organisms include coliforms, yeasts, moulds, E. coli, Salmonella, Shigella and Staphylococcus aureus. These are contaminants and are microbial associates of commercially sold Zobo drink. Their presence and levels are indicators of public health risk.

\section{References}

1. Zumbes JH, Dabo AD, Dakul DA, Afolabi SA, Dapiya MS (2014) Enter pathogenic bacterial contamination of some ready to eat foods sold in Jos metropolis. Nigeria Indian Journal of Applied research 4(7): 456458.

2. Ayandele AA (2015) Microbiological analysis of hawked kanun and Zobo drink within LAUTECH campus, Ogbomoso, Oyo state Nigeria. IOSR Journal of environmental science. Toxicology and Food Technology 9(10): 52-56.

3. Okereke CN, Iroka FC, Chukuruma MO (2015) Phytochemical analysis and Medicinal uses of Hibiscus sabdariffa. International Journal of Herbal Medicine 2(6): 16-19.

4. Egbere OJ, Anuonye JC, Challom PF, Kpara PV (2007) Effect of some preservation Techniques on the quality and storage stability of Zobo drink A Nigerian nonalcoholic beverage from Hibiscus Sabdariffa. Journal of Food Technology 5(3): 225-228.

5. Bamishaiye EI, Olayemi FF, Bamishaiye OM (2011) Effect of boiling time on mineral and vitamin c content of three varieties of Hibiscus sabdariffa drink in Nigeria. World journal of Agricultural science 7(10): 62-67.

6. Amusa NA, Ashaye OA, Aiyegbajo AA, Oladapo MO, Oni MO, et al. (2005) Microbiological and Nutritional quality of hawked sorrel drink (Soborodo) Widely Consumed and notable Nigeria Journal of Food Agriculture and Environment 3(3-4): 47-50.

7. Balakarami AU, Umarazulum, Mustafa AI (2016) Microbiological Analysis of Drinking water in Maiduguri Metropolis, Nigeria. International journal o t' Research 3(8).
8. Sylvester CI, Langlcy AO, Lovet TK (2015) A review of the quality assessment of Zobo drink consumed in Nigeria. ASIO journal of Microbiology Food Science and Biotechnological Innovation 1(1): 34-43.

9. Bello 00, Bello TK, Fashola MO, Oluwadan A (2014) Microbiological quality of some locally produced fruit juice in Ogun stale. South West Nigeria Journal of Microbiology Research 2(1): 001-008.

10. Bukar AM, Isa YM, Garba, Muhammad AA, Suleiman MM (2015) Bacteriological quality assessment of some snacks sold in fast food shops within Maiduguri Metropolitan council. Applied Research Journal 1(10): 501-505.

11. Nwachukwu E, Ezejiaku FC (2014) Microbial and physic chemical characteristics of locally produce pineapple juice treated with ginger and garlic. International journal of current microbiology and applied sciences. 3(4): 895-901.

12. Roseline EU, Regina E0, Ayodeji KR (2006) Microbiological and nutritional quality of diary product nono and wara. Microbiology nature and science 4(3): 37-40.

13. Cheesebrough M (2004) District Laboratory practice in Tropical countries Cambridge University press, Cambridge, UK 62-70.

14. Sebastia N, El Shenawy M, Manes J, Soriano JM (2012) Assessment of microbial quality ofcommercial and house made tiger-nut beverages. Letters in Applied Microbiology 5(54): 299-305.

15. Rugayya HM, Clement AY, Musa BB, Jamilu AZ, Adedayo MR (2016) Assessment of bacteria associated with ready to eat sold at Federal university Dutse, Jigawa state Nigeria. International journal of current research in biosciences and plant biology 3(4): 5-14.

16. Fowoyo PT (2012) Microbiological quality Assessment of Air contamination of Vended Food sold in the main market in Lokoja, Kogi state, Nigeria. Research Journal or Biological 7(9-12): 355-360.

17. Chidi F, Ezcama, Caroline II (2006) Microbiological and Sensory evaluation of Fermented rice snack (masa) supplemented with soybeans. Journal of Food technology 4(4): 354-349.

18. Sanni, AI, Adesulu AT (2013) Microbiological and physicochemical changes during fermentation of 


\section{Food Science and Nutrition Technology}

maize for masa production. African journal of microbiology research. 7(34): 4355-4362.

19. Olayemi F, Adebayo R, Muhammad R, Bamshaiye E (2011) The nutritional quality of three varieties of Zobo drink (Hibiscus sabdariffa) subjected to the same preparation condition. American Journal of Food Technology 6(8): 705-708.

20. Omemu AM, Obadina OA, Taiwo GJ, Obuotor TM (2014) Microbiological assessment and prevalence of food borne pathogens in slreet vended wara Nigerian while cheese. American Journal of Food and Nutrition 2(4): 59-62.

21. James MJ, (2001) Modern Food Microbiology $3^{\text {rd }}$ (Edn.), Tafa MC, Graw Hill publishers Co. Itd. PP 1 10125.

22. Musa AA, Hamza A (2013) Comparative Analysis of locally prepared KununAya Tiger nut milk consumed by student in Kaduna slate university Kaduna Nigeria. Science World Journal 8(2).

23. Raima OL (2013) Bacteriology quality of Zobo consumed in some part of Osun State Nigeria. Journal of Applied Science environmental management 17(1): 113-117.

24. Briade W, Oranusi S, Peter Ikechukwu AI (2012) Prospective in the hurdle techniques in the preservation of a non-alcoholic beverages, Zobo. African Journal of Food Science and Technology 3(2): 46-52.

25. Suleiman A, Zaria LT, Grema HA, Ahmadu P (2013) Antimicrobial resistant coagulase positive staphylococcus aureus from chicken in Maiduguri Nigeria. Sokoto Journal of Veterinary Science 11(1): 51-55.

26. Adedeji T, Oluwalana B (2013) Physicochemical, Sensory and Microbial Analysis of Wine Produced from Water melon (citrulluslanalus) and pawpaw (caricapapaya) Blend. Food Science and Technology and Quality Management Journal 19.

27. Adekayeni O, Sikiru S (2012) Microbiological, Physicochemical and Mineral quality Boreholes water inljebu land, Ogun state. Nigeria. International Journal of Food Science and Advance Technology 2(1).

28. Adebayo Tayo BC, Samuel UA (2008) Microbial quality and proximate composition of dried Hibiscus sabdariffa calxes in Uyo Eastern Nigeria. Malaysian Journal of Microbiology 5(1): 13-18.

29. Atinuke OI, Omobuwayo TO, Falade KO (2010) Production proximate analysis and shelf life studies of ready-to-eat rice and kilishi. American Journal of Food Science 4(5): 264-268.

30. Chikodili GAF, Onyedika CN, Chinyere IO, Chinedu CE, Kingsley CO, et al. (2015) Microbiological of Burukutu beverages produced in southern part of Nigeria. European Journal of experimental Biology 5(8): 1822.

31. Ezeama FC, Caroline II (2006) Microbiological and Sensory Evaluation of fermented rice snack (masa) supplemented with soybeans. Journal of Food Technology 4(4): 354-349.

32. Egbebi AO, Seidu KT (2011) Microbiological evaluation of suya (driedSmoked meat.) sold in Ado and Akure, south west Africa. European Journal of experimental biology (4): 1-5.

33. Elmahmood AM, Doughari JH (2007) Microbiological quality assessment of kunun-Zaki, beverage sold in Girei town Adamawa State, Nigeria. African Journal of Food Science 011-015.

34. Fowoyo PT (2012) Microbiological quality Assessment of Air contamination of Vended Food sold in the main market in Lokoja, Kogi state, Nigeria. Research Journal or Biological 7(9-12): 355-360.

35. Igwemma NC, Kolawole SA, Imran LA (2013) Effect of heating on vitamin $\mathrm{c}$ contentof some selected vegetables. International Journal of Scientific and Technological Research 2(11).

36. lheagwara MC, Okonkwo TM (2016) Effect of processing techniques on the microbiological quality of kilishi. Journal of Food Science and Technology 5(3): 225-228.

37. Manyi MM, Ola FI, Innocent 00 (2014) Microbiological and parasitic quality ofsuya (roasted beef) sold in Makurdi, Benue state, Nigeria. Academic journal 8(35): 3235-3242.

38. Makelele LK, Kazadi ZA, Oleko RW, Foma R, Rosette KM, et al. (2015) Microbiological quality of Food sold by street vendorin Kisangani Democratic Republic of Congo. African Journal of Food Science 9(5): 285-290. 


\section{Food Science and Nutrition Technology}

39. Igwemmar NC, AKolawole S, Imran IA (2013) Effect of heating on vitamin $\mathrm{c}$ content of some selected vegetables. International journal of scientific and technological research 2 (11): 209-212.

40. Ogiehor SI, Nwafor OE, Owhe Ureghe UB (2008) Changes in the quality of Zobo beverages produced from the Hibiscus sabdariffa (linnroscelle) and the effects of extract of ginger alone or in combination with refrigeration. African Journal of Biotechnology $7(8): 179-1180$.

41. Oranusi S, Olurunfemi OJ (2011) Microbiological safely evaluation of street vended ready to eat vended fruits sold in Ota Ogun state Nigeria. International
Journal of Researching Biological Sciences 1(6): 2732.

42. Raufa LA, Zongur L, Lawan FA, Bello HS, Adama MS, et al. (2014) Prevalence and antimicrobial profiles of salmonella sevovars from vegetables in maiduguri, North eastern Nigeria. Sokoto Journal of Veterinary Science 12(1): 23-28.

43. WHO (2007) Food Safety and Food borne Illness Fact Sheet 237 Review. World Health Organization Geneva, Switzerland. 